\title{
$\begin{array}{lllllllllllllllll}\mathbf{K} & \mathbf{O} & \mathbf{M} & \mathbf{U} & \mathbf{N} & \mathbf{I} & \mathbf{K} & \mathbf{A} & \mathbf{T} & \mathbf{Y} & \mathbf{N} & \mathbf{A} & \mathbf{U} & \mathbf{K} & \mathbf{O} & \mathbf{W} & \mathbf{E}\end{array}$
}

KWARTALNIK HISTORII KULTURY MATERIALNEJ 69 (3), 2021 PL ISSN 0023-5881; e-ISSN 2719-6496 www.iaepan.edu.pl the CC BY 4.0 license (https://creativecommons.org/licenses/by/4.0/)

DOI: $10.23858 /$ KHKM69.2021.3.007

\author{
Jacek Pielas
}

\section{Taksy mobiliów szlacheckich z krakowskich ksiąg grodzkich z końca XVII i początku XVIII wieku}

\begin{abstract}
Abstrakt: Artykuł poświęcony jest analizie taks mobiliów szlacheckich. Podstawę źródłową stanowi 31 wycen ruchomości szlacheckich z krakowskich ksiąg grodzkich relacji z lat 1685-1710. Dokumenty te przeanalizowano pod względem budowy i zawartości. Podana w taksach wartość ruchomości pozwala na poznanie rzeczywistej, wyrażonej w pieniądzu, wartości określonych ruchomości szlacheckich w badanym okresie, nie tylko tych najcenniejszych, ale też starych i zużytych. Podkreślono potrzebę kontynuowania badań nad tego typu źródłami. W aneksie zamieszczono edycję jednego z omawianych dokumentów - otaksowanie futer, odzieży, srebra i chust po zmarłych małżonkach Chrząstowskich z $1686 \mathrm{r}$.

Abstract: The article presents the analysis of the valuations of the nobility's movables. The discussion is based on the analysis of 31 written records - valuations of nobles' movables from the records of the Kraków nobility court from the years 1685-1710. These documents were analysed for their structure and content. The value of the objects given in valuation reports enables us to learn the real value, expressed in monetary terms, of certain nobles' movable assets in the discussed period — not only of the most valuable possessions but also of old and worn-out ones. This paper emphasises the need to continue research on sources of this type, while the appendix contains an edition of one of the documents in question - a valuation report concerning furs, clothing, silver, and scarves left by the deceased married couple Chrząstowski made in 1686.
\end{abstract}

Słowa kluczowe: wartość materialna, ruchomości, szlachta, Małopolska, taksa

Key words: material value, moveable property, nobility, Lesser Poland, valuation report

Publikacji historycznych opisujących szlachecki „świat rzeczy” dawnej Rzeczypospolitej przybywa z każdym rokiem. Oprócz dwóch fundamentalnych prac — autorstwa Andrzeja Pośpiecha i Jarosława Dumanowskiego powstało w ostatnich latach wiele opracowań, artykułów i przyczynków podejmujących zagadnienia związane z materialnymi warunkami życia szlachty, biedą i bogactwem, szlachecką konsumpcją, budowaniem tożsamości społecznej i rywalizacją w obrębie stanu, recepcją nowinek z zagranicy w zakresie świata szlacheckich mobiliów, indywidualnymi zainteresowaniami i mentalnością szlachty lub też konfliktami o podłożu majątkowym ${ }^{1}$. Publikacje te powstawały przede wszystkim na podstawie analiz szlacheckich testamentów oraz inwentarzy mienia ruchomego, przede wszystkim inwentarzy pośmiertnych mienia i rejestrów wypraw kobiet wychodzących za mąż. Niejednokrotnie przy tym podkreślano, że w części wspomnianych źródeł sporządzająca je szlachta zaznaczała wartość materialną (pieniężną) poszczególnych rzeczy lub ich kategorii. Z reguły z zapisów w tego rodzaju źródłach trudno jednak wywnioskować, kto i kie-

1 Pośpiech A. 1992; Dumanowski J. 2006 (tu zgromadzona literatura przedmiotu do 2008 r.). Przegląd dotychczasowych opracowań, zwalniający od ich ponownego przywoływania, zob. m.in.: Pielas J. 2013, s. 104-106; Penkała-Jastrzębska A. 2020, s. 34-40. 
dy je oszacował, czy miał do tego odpowiednią wiedzę i umiejętności, a przede wszystkim, na ile podana wartość odpowiadała ówczesnej, rzeczywistej cenie ruchomości². W tej sytuacji źródłem, któremu warto poświęcić baczniejszą uwagę, zwłaszcza w kontekście rozważań o rzeczywistej materialnej wartości szlacheckich ruchomości, są taksy mobiliów. Dotychczas ten rodzaj źródeł w odniesieniu do szlachty nie był przedmiotem dokładniejszej obserwacji ${ }^{3}$.

Celem niniejszego artykułu jest prezentacja i charakterystyka wspomnianych taks jako źródła do badań kultury materialnej stanu uprzywilejowanego. Zasadniczą uwagę skoncentrowano na kwestiach związanych z genezą powstawania wycen, osobami dokonującymi oszacowania wartości rzeczy, wpisywaniem ich do ksiąg grodzkich, stroną formalną tego typu dokumentów i ich treścią oraz znaczeniem otaksowań. W aneksie do artykułu zamieszczono edycję jednego z najbardziej interesujących spośród odnalezionych dokumentów. Zawiera on wycenę ruchomości z oszacowaniem wartości czterech kategorii mobiliów. Podane do druku otaksowania z 2 grudnia 1686 r. obejmują futra, odzież, srebro i chusty po zmarłych małżonkach Chrząstowskich. W dokumencie tym, prócz dokładnych informacji o wartości i próbie srebra należącego do wspomnianej pary, ciekawe jest — rzadko pojawiające się w źródłach — oszacowanie tzw. chust (obrusów, poszewek, ręczników, koszulek itp.) dokonane przez trudniące się tym mieszczki krakowskie, nie zaś przez reprezentantów cechu miejskiego.

Po przeprowadzeniu analizy różnorodnych zapisów w księgach grodzkich dotyczących szlacheckich ruchomości, pod pojęciem taksy mobiliów rozumiem sporządzone na zamówienie zainteresowanego oszacowanie wartości ruchomości określonej kategorii, wykonane w określonym czasie przez przedstawicieli cechów miejskich lub osoby trudniące się w praktyce szacowaniem przedmiotów i uwierzytelnione podpisami osób przeprowadzających wycenę oraz — w przypadku przedstawicieli cechów — także pieczęcią cechową.

Podstawę źródłową prezentowanych ustaleń stanowią taksy mobiliów znajdujące się w księgach grodzkich krakowskich relacji z lat 1685-1710. Wybór tego okresu podyktowany był obserwacjami dokonanymi podczas wcześniejszych kwerend w tychże księgach, z których wyraźnie wynikało, że im bliżej końca XVII stulecia, tym oszacowania wartości ruchomości szlacheckich pojawiały się częściej. Poza tym, jak wiadomo, przełom obu stuleci był czasem intensywnych przemian materialnych i wzorów społecznej konsumpcji ${ }^{4}$. Odnaleziono w sumie 12 dokumentów będących taksami mobiliów oraz trzy rejestry ruchomości, w których zamieszczono urzędowe wyceny ich wartości. W dokumentach tych znajduje się łącznie 31 taks ruchomości szlacheckich ${ }^{5}$ i to one stanowią podstawę poniższych rozważań. Warto dodać, że w tych samych księgach odnaleziono 107 rejestrów ruchomości, w zdecydowanej większości będących inwentarzami pośmiertnymi mienia. Porównanie liczby rejestrów ruchomości z liczbą dokumentów z wycenami ruchomości, lub nawet z liczbą samych otaksowań wskazuje wyraźnie, że omawiane rejestry zdecydowanie rzadziej wpisywane były przez szlachtę do akt grodzkich. Ponadto we wspomnianych inwentarzach ruchomości tylko w 14 przypadkach (nieco ponad $13 \%$ wszystkich inwentarzy z tego okresu) odnotowano mobilia z podaniem ich szacunkowej wartości przez osobę sporządzającą rejestr ${ }^{6}$.

2 Dumanowski J. 2006, s. 286-295; Penkała-Jastrzębska A. 2020, s. 39-40.

3 W odniesieniu do mieszczaństwa dla drugiej połowy XVII w. dostrzegano tendencję do pojawiania się szacunku wartości przedmiotów (m.in. Klonder A. 2000, s. 19-20). Szeroko na temat wycen ruchomości mieszczańskich przez rzemieślników i przedstawicieli cechów wypowiedziała się ostatnio Katarzyna JustyniarskaChojak (Justyniarska-Chojak K. 2020, s. 57-63).

4 Zob.: Pielas J. 2013, s. 112; Kicińska U. 2017, s. 469-470.

5 Oprócz 31 oszacowań ruchomości szlacheckich odnaleziono również taksę ruchomości mieszczańskich, dwie wyceny koni oraz jedną wołów, ANKr., CCR, sygn. 786, s. 1945-1953, 2483; sygn. 791, s. 215-216, $1594-1595$.

${ }^{6} \mathrm{O}$ zjawisku nieczęstego podawania wartości mobiliów w inwentarzach pośmiertnych, zob. m.in.: Pośpiech A. 1992, s. 39, 46-47; Dumanowski J. 2006, s. 286-287. 
Wyodrębnienie taks mobiliów spośród wielkiej liczby różnorakich zapisów w krakowskich księgach grodzkich serii relationes wydaje się z pozoru nietrudne. Kierując się bowiem tytułem zapisów w języku łacińskim, wyróżnionym przez wielkość i pogrubienie, w 11 przypadkach (73\%) odnalezione dokumenty z szacunkami dóbr ruchomych zawierały w nagłówku łacińskie słowo taxa. Zazwyczaj tytułom tym nadawano w kancelarii urzędu grodzkiego formę w rodzaju: Oblata taxae rerum morte olim Szonowskiego relictorum, lub Oblata taxae rerum post mortem Gnosi Chetmski relictorum, ale także dodając informację o wpisie rejestru mienia, np. Oblata regestri rerum cum taxa post mortem G. Gołuchowskiego, maritum ipsius, conscriptis ${ }^{7}$. Niekiedy wszakże (cztery przypadki) taksy znalazły się w dokumentach o tytułach typowych dla oblat inwentarzy pośmiertnych ruchomości, np. Oblata regestri rerum mobilium morte olim GG. Chrąstowskich derelictorum ${ }^{8}$. Dopiero na podstawie treści aktu ustalono, że mamy do czynienia z typowym oszacowaniem wartości przedmiotów lub wyceną włączoną w skład rejestru ruchomości.

Podobnie jak w przypadku większości dokumentów wnoszonych do akt grodzkich serii relacji, różny jest okres dzielący datę powstania dokumentu od terminu jego oblaty w księgach. W sześciu przypadkach (40\%) był to ten sam dzień wpisu do ksiąg (dwukrotnie), albo następny (w 2 przypadkach) lub kilka dni później (też 2). Zatem zamawiający taksę, korzystając z pobytu w Krakowie, starał się tuż po jej uzyskaniu wpisać ją do akt. Trzy otaksowania zarejestrowano w księgach w odstępie od półtora do dwóch miesięcy, dwa - w okresie kilku miesięcy, dwa inne - w terminie ok. jednego roku, zaś jedną — przed upływem dwóch lat. Najpóźniej oblatowaną wyceną było nakazane dekretem sądowym powtórne oszacowanie klejnotów zmarłego Stanisława Witowskiego, kasztelana sandomierskiego, przeprowadzone w końcu marca 1684 r., po ośmiu latach od sporządzenia pierwszej taksy9 . Dłuższy czas pomiędzy powstaniem wyceny a jej oblatowaniem dowodzi, że w większości przypadków podanie jej do ksiąg wynikało z potrzeby urzędowego potwierdzenia dokumentu, w związku z aktualnymi potrzebami procesowymi. Poświadczona kopia miała bowiem służyć jako środek dowodowy w procesach sądowych w sporach natury prawno-majątkowej. W analogiczny sposób postępowano przy wpisywaniu do ksiąg sądów szlacheckich chociażby intercyz przedślubnych ${ }^{10}$.

Osoby przybywające do urzędu grodzkiego przynosiły różne liczby wycen w celu ich oblatowania. W poszczególnych dokumentach wpisanych do akt odnotowano jedną (w 5 dokumentach), dwie (w 5) i trzy taksy (w 4). W związku z tym można sądzić, że zdecydowanie przeważały (w stosunku 2:1) dokumenty z co najmniej dwiema taksami. Potwierdzają to również dwa dokumenty z czterema wycenami. To oszacowania wartości klejnotów, futer, odzieży i siodeł wpisane do ksiąg w sierpniu 1704 r. przez jednego z sukcesorów Mikołaja Mozgawy, oraz wspomniane otaksowania wartości futer, odzieży, srebra i chust po zmarłych małżonkach Chrząstowskich z 2 grudnia 1686 r. ${ }^{11} \mathrm{~W}$ sytuacji, gdy dysponujemy wycenami kilku kategorii mobiliów jednej osoby lub małżeństwa, można domniemywać, że dla celów spadkowych oszacowano całość lub większość ruchomości spadkodawcy. Warto dodać, że pojedynczymi taksami oblatowanymi w grodzie były wyłącznie oszacowania klejnotów i kruszców, czyli zwykle przedmiotów najcenniejszych w zbiorze ruchomości, podlegających dziedziczeniu ${ }^{12}$. To one zazwyczaj dzielone były w procesie spadkobrania w pierwszej kolejności, zatem właściwe określenie ich wartości miało dla sukcesorów podstawowe znaczenie ${ }^{13}$.

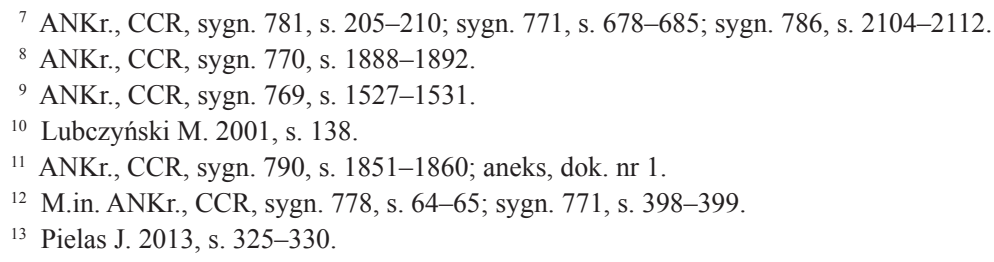


W analizowanych źródłach zdecydowana większość wycen była datowana (27 taks — 87\%). W czterech przypadkach nie odnotowano, kiedy ją sporządzono, przy czym dwie z nich nie zostały wykonane przez przedstawicieli cechów (taksy chust i pościeli) ${ }^{14}$. Jedynie w taksie obejmującej ozdobne siodła przedstawiciele cechu haftarzy nie podali czasu przeprowadzonych czynności ${ }^{15}$. W jednym przypadku otaksowanie klejnotów dołączone zostało do datowanego (na ten sam dzień?) oszacowania sporządzonego przez innych złotników z tego samego cechu ${ }^{16}$.

Niemal wszystkie analizowane taksy opatrzone zostały podpisami osób, które przeprowadziły oszacowanie. Tylko jeden dokument (z trzema wycenami) — choć niewątpliwie z uwagi na zawartość, sporządzony na podstawie oszacowań dokonanych przez przedstawicieli cechów — nie zawiera podpisów ${ }^{17}$.

Dokumenty z wycenami ruchomości spisywane przez członków cechów miejskich, prócz wspomnianego uwierzytelnienia podpisami, były też pieczętowane. Wprawdzie w kilku przypadkach we wpisach do ksiąg indukty brak informacji o pieczęci ${ }^{18}$, jednak na ogół przed lub po podpisach zanotowano, że pod dokumentem pieczęć została przyłożona. Świadczą o tym zapisy: locus sigilli, locus sigilli contuberni pellionum, locus sigilli contuberni sartorum, locus sigilli contuberni plumariorum. Pieczęcią tą była — jak jasno wynika z kilku wzmianek — pieczęć cechowa.

Wśród 31 odnalezionych taks zdecydowanie przeważają te wykonane na zamówienie szlachty przez przedstawicieli cechu złotników krakowskich, szacujących najcenniejsze mobilia: złoto, srebro i klejnoty (16 taks, nieco ponad 50\% wszystkich analizowanych). Prawo cechowe złotników krakowskich pozostawiało taksowanie wartości przedmiotów w wyłącznej gestii starszych cechu. Potwierdzają to podpisy pod wycenami, wskazujące na czynność szacowania przedmiotów dokonaną przez seniorów cechowych (zazwyczaj dwóch, w tym niejednokrotnie przez prymasa) ${ }^{19}$. Otaksowania odzieży wykonywane były z reguły przez dwóch starszych krakowskiego cechu krawieckiego (7 taks, 22,6\%), w tym prymasa, cechmistrza i pisarza cechowego ${ }^{20}$. Pięć taks futer $(16 \%)$ sporządzonych zostało przez starszych krakowskiego cechu kuśnierzy, w tym jedna przez jednego starszego ${ }^{21}$. W dwóch przypadkach oszacowaniu podlegały chusty (chusty, bielizna, pościel), co zawsze wykonywały dwie kobiety ${ }^{22}$. W jednej niedatowanej taksie, przygotowanej zapewne na początku lutego 1700 r., pod wyceną postawiły krzyżyki nieumiejące pisać Regina Kwiatkiewiczowa i Marianna Wójtowiczowa. Jak wynika z treści nagłówka dokumentu, taksowały one w Krakowie różne rzeczy, różnym osobom $^{23}$. Jedyny w analizowanej grupie szacunek siodeł, a właściwie ozdób na siodłach, przeprowadzony został przez starszego i podstarszego krakowskiego cechu haftarzy ${ }^{24}$.

${ }^{14}$ ANKr., CCR, sygn. 770, s. 1891-1892; sygn. 786, s. 2110-2111.

15 ANKr., CCR, sygn. 790, s. 1859-1860.

${ }^{16}$ ANKr., CCR, sygn. 769, s. 891-895.

17 ANKr., CCR, sygn. 771, s. 678-685.

18 ANKr., CCR, sygn. 769, s. 891-895, 1527-1531; sygn. 770, s. 374-378, 1888-1892.

19 Według statutu krakowskiego cechu złotniczego ,szacunek i próbowanie wyrobów złotniczych należały do zakresu działalności starszych”, Lepszy L. 1898, s. 228. W publikacji tej również o funkcjonowaniu i wyborze starszych cechowych i prymasa, szczególnie na s. 190-192, 222, gdzie także przywołane zostały nazwiska złotników i jubilerów z XVII w. odnotowanych w badanych dokumentach. Tylko w jednym przypadku pod taksą widnieje podpis jednego starszego, ANKr., CCR, sygn. 791, s. 326.

${ }^{20}$ M.in. ANKr., CCR, sygn. 781, s. 208, 374-378. Wyjątkowo jedną z taks odzieży wykonało aż czterech starszych cechu krawieckiego, ANKr., CCR, sygn. 786, s. 2109-2110.

${ }^{21}$ ANKr., CCR, sygn. 770, s. 1888.

${ }^{22}$ ANKr., CCR, sygn. 786, s. 2110-2111; sygn. 770, s. 1891-1892.

${ }^{23}$ ANKr., CCR, sygn. 786, s. 2111.

${ }^{24}$ ANKr., CCR, sygn. 790, s. 1859-1860. 
Odnośnie do powodów, dla których zamawiano taksy, analizowane źródła i niekiedy towarzyszące im w księgach inne wpisy, niewiele wiadomo ${ }^{25}$. W zdecydowanej większości z faktu, że w formule oblatacyjnej lub nagłówku dokumentu wyceny wspomina się o rzeczach po zmarłym mężu, żonie i małżonkach, wynika, że zostały one zamówione w związku z mającym nastąpić postępowaniem spadkowym. Najbardziej jest to czytelne w przypadku otaksowania ruchomości po śmierci Samuela Chełmskiego, z 16 maja 1685 r. Było ono podstawą do przeprowadzenia podziału ruchomości przez jego spadkobierczynie, który to akt podziałowy wpisano do ksiąg wraz $\mathrm{z}$ taksą ${ }^{26}$. W nagłówku oszacowania wartości rzeczy po zmarłym Michale Mozgawie (z 6 sierpnia 1704 r.) również jednoznacznie wskazano, że zamawiającymi byli jego siostrzeńcy jako sukceso$\mathrm{rzy}^{27}$. Cele sukcesyjne również legły u podstaw kolejnej wyceny tych samych mobiliów (z 29 marca 1684 r.), nakazanej przez dekret grodzki osiem lat po pierwszej taksie, w sporze między spadkobiercami Stanisława Witowskiego, kasztelana sandomierskiego ${ }^{28}$.

$\mathrm{Na}$ istotną rolę urzędowych oszacowań w procesie dziedziczenia wskazują liczne źródła dokumentujące spadkobrania szlacheckich ruchomości, w tym akty podziału dóbr ziemskich i ruchomych oraz testamenty ${ }^{29}$. W związku z generalną zasadą równości działów (sched) dóbr ruchomych obejmowanych przez sukcesorów niezbędne było precyzyjne określenie masy spadkowej, aby można było dokonać równego podziału. Należy dodać, że niejednokrotnie po wycenie sukcesorzy decydowali się na zbycie mobiliów i podzielenie uzyskanej gotówki ${ }^{30}$.

Szacowanie wartości ruchomości było również podyktowane chęcią ich sprzedaży, w celu otrzymania środków pieniężnych. Powody takiego postępowania mogły być różne. I tak, np. Stefan Koryciński, kanclerz wielki koronny, w kodycylu do testamentu spisanym 7 grudnia 1657 r. wskazał, biorąc za podstawę wycenę rzeczy srebrnych, by spadkobiercy starali się sprzedać ,[...] dzbany wielkie srebrne dwa proby 13tey, wielkie, wierzchem mieyscami złociste, wewnątrz wcale wyzłocone, z herbami: ważą grzywien 128 i łotów 5, grzywna po złotych 30, uczyni to złot. 3480. Konwie srebrne dwie wielkie proby 13 tey, wierzchem mieyscami, wewnątrz cale złociste i z herbami: ważą grzywien 145 łot. 9 1/2, grzywna po zł. 30 uczyni to zł. 4365. A że się to tak nie może przedać (lubo na tem trzeba stawać bo to kupi kto znaczny), to gdyby się nie mogło przedać tą ceną, tedy pozłotę spędzić [...], a potem samo srebro które jest proby 13 tey na dziewiętnaście złotych grzywna wynidzie, i tak nie będzie szkody ani na srebrze ani na złocie". Pieniądze ze sprzedaży wymienionych ruchomości miały być przeznaczone na odnowienie kościoła Św. Szczepana w Krakowie ${ }^{31}$. Niejednokrotnie o zbyciu rzeczy po ich oszacowaniu decydowała też aktualna, pilna potrzeba. Takie niecodzienne okoliczności potwierdza chociażby informacja w testamencie Zofii Gniewoszowej, starościny radomskiej, z czerwca 1660 r., mówiąca o konieczności sprzedaży przez testatorkę srebra i sześciu guzów rubinowych w czasie ucieczki przed nieprzyjacielem na teren Wielkiego Księstwa Litewskiego ${ }^{32}$.

Wyceny zamawiano powszechnie również w celu zastawienia ruchomości. Akty ostatniej woli wielokrotnie wzmiankują o pozostających w zastawie przedmiotach, które miały być potem

${ }^{25} \mathrm{~W}$ dwóch przypadkach nie wiadomo, dlaczego szlachcice zamówili oszacowanie wartości srebra i klejnotów. Natomiast taksa powstała 22 czerwca 1684 r. na zamówienie Jerzego Kosickiego a objęła ruchomości oddane mu wcześniej w depozyt przez małżonków Bonawenturę i Mariannę Kosickich, ANKr., CCR, sygn. 771, s. 398-399; sygn. 778, s. 64-65; sygn. 769, s. 891-895.

${ }^{26}$ ANKr., CCR, sygn. 771, s. 678-685.

27 ANKr., CCR, sygn. 790, s. 1851-1860.

28 ANKr., CCR, sygn. 769, s. 1527-1531.

29 Zob. m.in.: Cui contingit. 2005, s. 56, 158; Pielas J. 2013, s. 326.

${ }^{30}$ Pielas J. 2013, s. 323, 326-330.

31 Hoszowski K. 1862, s. 105.

32 Cui contingit. 2005, s. 119. 
wykupione przez spadkobierców zmarłego ${ }^{33}$. Przeprowadzenie wyceny jednego lub kilku cenniejszych wyrobów niejednokrotnie spowodowane było koniecznością oddania ich w zastaw.

Wymienione powyżej, najczęstsze przyczyny zamawiania wycen mobiliów, potwierdzają także analizy przeprowadzone ostatnio przez Katarzynę Justyniarską-Chojak dla środowiska mieszczańskiego. Autorka wykazała, że oprócz spadkobrań, otaksowania zamawiano również ze względu na konieczność zastawienia ruchomości, sprzedaży mobiliów na bieżące wydatki lub też działania tutora $\mathrm{w}$ imieniu małoletniego ${ }^{34}$.

Ile ruchomości jednorazowo szacowano? Szczegółowa statystyka, jak się wydaje, umożliwia odpowiedź w zasadzie tylko na pytanie o poziom zamożności osoby posiadającej wyceniane mobilia, ale też tylko wówczas, gdy mamy pewność (co wszakże rzadkie), że oszacowana została większość cenniejszych rzeczy. Rozpiętość w zakresie liczby rzeczy w taksach jest bowiem znacząca. Zdarzyło się, że otaksowaniu podlegał tylko jeden przedmiot, np. perły kałakuckie wartości 148 tynfów (dokument z 16 września 1698 r.) . $^{35}$. Niektóre wyceny, zwłaszcza klejnotów i kruszców, dotyczyły kilku ruchomości (np. z 3 lutego 1700 r. i 19 stycznia 1694 r.) ${ }^{36}$. Jedna $\mathrm{z}$ taks objęła cztery futra (16 maja 1685 r. $)^{37}$. Natomiast otaksowaniu klejnotów, złota i srebra po śmierci Michała Mozgawy (z 6 sierpnia 1704 r.) podległo 35 drogocennych mobiliów ${ }^{38}$. Jeszcze większą ich liczbę wymieniono w szacunku klejnotów po zmarłych małżonkach Kosickich (z 22 czerwca 1684 r.) $)^{39}$.

Jakkolwiek z powodów oczywistych taksowano zazwyczaj rzeczy cenne lub najcenniejsze, to decydowano się również na zamówienie wyceny ruchomości starych i „przechodzonych”, a więc od dłuższego czasu służących właścicielowi lub będących w złym stanie ${ }^{40}$. Dotyczyło to, co nie dziwi, przede wszystkim odzieży i futer. I tak, np. w wycenie wartości ubrań i futer po śmierci szlachetnego Samuela Kernera (z 22 stycznia 1705 r.), który miał wszakże złoto i klejnoty o łącznej wartości 2042 tynfów, oszacowano m.in. „Kontusz niebieski wytarty i poplamiony waloru zł 30”, „Item futro pod kontuszem granatowe zażywane waloru zł 30, przy tym futrze ogonki sobole zażywane waloru zł 40. Item futro ślamowe pod kontuszem lisie zażywane, schodzone dobrze, waloru zł 60"41. Podobnie w taksie ubiorów i futer po urodzonym Stanisławie Szonowskim (z 2 grudnia 1696 r.) znalazł się m.in. ,[...] kontusz pomarańczowy sukienny ze sznurkiem jedwabnym, bardzo poblakowany, jest waloru zł 20 i 6”, [...] „Futro pod kontuszem pupkowe, które dobrze zażywane, bramowane ogonkami sobolimi, na całym przodku ogonki i pod kołnierzem lewym do pół przodka, także zażywane dobrze, za które szelągami zł 80. Futro grzbietowe lisie zażywane, przodki odnowione, w zadzie bardzo stare, za które szelągami zł 40 i 5"42. Mikołaj Starczowski, wdowiec po Mariannie, we wrześniu 1698 r. oddał do otaksowania u krakowskich krawców m.in. „Manto kitajkowe popielate, poplamione i zabrukane dużo, waloru zł 10. Manto stare [ś']lamowe, listwa kitajkowa cytrynowa, kilka razy przerabiana i podarta, waloru zł 10. Manto całe rąbkowe w paski, podarte, waloru zł 2"43. Otaksowania rzeczy starych, podniszczonych i zużytych miały na celu sprecyzowanie, za jaką cenę można je zbyć i tym samym, ile gotówki można za nie jeszcze uzyskać.

${ }_{33}$ M.in. Cui contingit. 2005, s. 116; Klint P. 2011, s. 84, 206.

34 Justyniarska-Chojak K. 2020, s. 57-63 (autorka podkreśla także, że niejednokrotnie nie można ustalić, co legło u podstaw zamówienia taksy).

${ }_{35}$ ANKr., CCR, sygn. 783, s. 2712.

${ }^{36}$ M.in. ANKr., CCR, sygn. 786, s. 2108; sygn. 778, s. 65.

37 ANKr., CCR, sygn. 771, s. 681.

38 ANKr., CCR, sygn. 790, s. 1851-1852.

39 ANKr., CCR, sygn. 769, s. 891-895.

40 Por. m.in. Pośpiech A. 1996, s. 377-379; Głowacka-Penczyńska A. 2013, s. 330-331.

${ }^{41}$ ANKr., CCR, sygn. 791, s. 327-328.

42 ANKr., CCR, sygn. 781, s. 208-209.

${ }^{43}$ ANKr., CCR, sygn. 783, s. 2713-2714. 
Wartość szacowanych ruchomości wyrażano w funkcjonującym wówczas pieniądzu, najczęściej w złotych. We wszystkich taksach odzieży, futer, chust i ozdobnych siedzeń, wartość rzeczy podano wyłącznie w złotych ${ }^{44}$. Znacznie większą różnorodność w tym względzie widać w wycenach klejnotów, złota i srebra. Niejednokrotnie wartość takich przedmiotów określano bowiem w talarach i tynfach, niekiedy od razu podając równowartość we florenach, przy zastosowaniu odpowiedniego przelicznika ${ }^{45}$.

W szacunkach srebra dokładnie określano zarówno wagę kruszcu — w grzywnach i łutach (łotach), jako jednostkach probierczych srebra — jak i próbę metalu. Jednocześnie w większości z nich podawano wartość grzywny kruszcu określonej próby ${ }^{46}$. Przykładem może być wycena wyrobów ze srebra zamówiona przez Bogusława Kazimierza Ulatowskiego z 14 marca 1687 r.: „W tacach czterech próby trzynastej, ważą grzywien siedm, łotów cztery, grzywna po zł 40. Strzemion parę próby jedenastej, ważą grzywien cztery, łotów trzynaście, grzywna po zł 36. Cugle srebrne próby jedenastej, ważą grzywien cztery i łot, grzywna po zł 36. Uździenice dwie próby jedenastej, ważą grzywien dwie, łotów dwa, grzywna po zł 36. Rząd drugi dwoisty w pukle odlewany — zł 350”47. Dla porównania warto przywołać fragment wyceny naczyń ze srebra po zmarłej Zofii Radoszowskiej z 20 maja 1693 r.: „Naprzód miednica z nalewką auszpurską próby trzynastej, waży grzywien ośminaście, pstro złocista, taksa jej grzywna jedna po zł 40 — suma zł 720. Miednica gładka próby trzynastej, ranty złociste, waży grzywien ośm, łotów jedenaście, grzywna po zł 36 — summa facit zł 313 [..." $]^{\text {48 }}$.

Waga złota wyrażana była w czerwonych złotych, przy czym, według wzmianki w taksie z 1685 r., jeden czerwony złoty miał wartość 10 zł $^{49}$. Dwa wyjątki z analizowanych wycen to: „Łańcuszków sześć w grochowe ziarka, ważą czerwonych zł pię[ć]dziesiąt i półdziewięta, jeden czerwony złoty po zł 10. Łańcuszek w grochowe ziarka drobny, odlewany alias lity, waży czerwonych złotych półósma — zł 70 i 5"50 (dokument z 22 czerwca 1684 r.), „Łańcuch w kółka młyńskie złota węgierskiego waży czerwonych złotych pięćdziesiąt dwa, wytrącono na smelc, taksa po zł 11 - summa facit zł 572. Łańcuszek śklący złota węgierskiego waży czerwonych złotych pięć i pół — zł 60, gr 15. Łańcuszek w grochowe ziarno złota węgierskiego waży czerwonych złotych sześć, po złotych jedenaście — summa facit zł 66"51 (z 20 maja 1693 r.).

Podana w taksach wartość mobiliów w zestawieniu z ich opisami, jak się wydaje, nierzadko dokładniejszymi niż zawarte w inwentarzach pośmiertnych ruchomości i innych spisach mienia $^{52}$, pozwala na poznanie rzeczywistej, jednoznacznie wyrażonej w pieniądzu, wartości określonych rodzajów ruchomości szlacheckich w badanym okresie. Możliwości poznawcze w tym względzie chyba najlepiej prezentują dwie taksy tych samych ruchomości, zamówione w odstępie 8 lat przez spadkobierców Stanisława Witowskiego, kasztelana sandomierskiego. Po pierwszym oszacowaniu części mobiliów po Witowskim, 28 marca 1676 r. dekretem sądo-

${ }^{44} \mathrm{~W}$ dwu taksach futer zaznaczono ich wartość „,szelągami w złotych”, ANKr., CCR, sygn. 781, s. 208-209, $377-378$

${ }^{45}$ M.in. ANKr., CCR, sygn. 769, s. 891-195; sygn. 790, s. 1851-1852; sygn. 791, s. 323-328; sygn. 793, s. 251-252; sygn. 769 , s. 891-895.

${ }^{46}$ M.in. ANKr., CCR, sygn. 770, s. 1888-1892; sygn. 771, s. 398-399, 678-685; sygn. 769, s. 1527-1531; sygn. 777, s. 925-930; sygn. 791, s. 323-328.

${ }^{47}$ ANKr., CCR, sygn. 771, s. 399.

${ }^{48}$ ANKr., CCR, sygn. 777, s. 930.

${ }^{49}$ ANKr., CCR, sygn. 769, s. 893.

${ }^{50}$ ANKr., CCR, sygn. 769, s. 893.

${ }^{51}$ ANKr., CCR, sygn. 777, s. 931; por. też: ANKr., CCR, sygn. 786, s. 2108; sygn. 790, s. 1854-1855; sygn. 778 , s. 65.

${ }^{52}$ Interesujące byłoby porównanie szczegółowości opisów ruchomości zawartych w dokumentach wycen $\mathrm{z}$ opisami inwentaryzowanych $\mathrm{w}$ innego typu spisach mienia. Naświetlenie tego problemu wymaga odrębnego opracowania. 
wym nakazano ponowną taksę tych samych przedmiotów srebrnych, którą wykonali złotnicy krakowscy w dniu 29 marca 1684 r. ${ }^{53}$ Wszystko wskazuje na to, że było to działanie stanowiące następstwo przeprowadzonego 26 października 1682 r. podziału dóbr ziemskich po Witowskim, w którym zapisano: „Rzeczy ruchome, iż jeszcze dotychczas nie są podzielone, tedy się nimi JMM strony obiedwie aequaliter, czas na to naznaczywszy, podzielić mają, których to rzeczy podział in seorsivo regestro ma być spisany" ${ }^{\prime 4}$. W obu taksach w zasadzie nie ma różnic w opisie przedmiotów, dostrzegalna jest natomiast w wartości grzywny srebra określonej próby — w drugiej taksie z reguły ma ona wyższą wartośćc 55 .

Jakie zatem znaczenie, w świetle zaprezentowanych ustaleń, w badaniach kultury materialnej szlachty doby nowożytnej należy przypisać otaksowaniom mobiliów? Z pewnością urzędowe oszacowania wartości ruchomości mają walor wysokiej wiarygodności w kontekście określania realnej, materialnej (pieniężnej) wartości przedmiotów stanowiących szlachecki „świat rzeczy”. Nie dostrzega się bowiem w zasadzie żadnych przesłanek, by sądzić, że rzeczoznawcy, będący w większości wpływowymi członkami cechów miejskich, mogli nierzetelnie określać wartość mobiliów. Zwłaszcza, że pobierali z tego tytułu opłaty, istotny składnik funkcjonowania ich korporacji.

W związku z powyższym można przyjąć, że taksy to wiarygodny przekaz o rzeczywistej wartości szacowanych przedmiotów. Daty dzienne przeprowadzenia wyceny, podane zazwyczaj w analizowanych dokumentach, pozwalają ustalić, jaką wartość miały odnotowane wyroby w ściśle określonym czasie. Co więcej, oprócz wartości mobiliów wykonanych z metali szlachetnych, zawierają również dane o wadze kruszcu, a w przypadku srebra - o obowiązującej wówczas wartości konkretnej jego próby. To niewątpliwie istotne informacje, szczególnie dla badaczy dawnego złotnictwa i jubilerstwa ${ }^{56}$. Rzadziej, ale jednak, zachowane są też wyceny rzeczy starych, co pozwala zorientować się, jaką cenę można było uzyskać w dużym mieście za zużytą odzież szlachecką. W tej sytuacji wykazy sporządzone na podstawie wycen konkretnego rodzaju mobiliów umożliwić mogą poznanie rozpiętości wartości określonych ruchomości oraz przedmiotów tej samej kategorii w różnych latach.

Przekaz urzędowych otaksowań ruchomości zdecydowanie zatem przewyższa wiarygodnością informacje z innego rodzaju źródeł w kwestii ustalania rzeczywistej wartości rzeczy ruchomych. $Z$ pewnością pod tym względem nie mogą się im równać akty ostatniej woli, w których testatorzy niekiedy podawali szacunkową wartość części mobiliów. Nasuwa się zatem pytanie, na jakiej podstawie to czynili? Niekiedy testatorzy przypominali sobie sumę (ale czy dokładną?), którą wydali na zakup, lub za którą zastawili konkretną ruchomość. Śladem tego są stwierdzenia w rodzaju: „mam wstęgę diamentową i pierścień diamentowy swój ślubny w zastawie. [...] Za samą wstęgę dałam była zł 600, za pierzcień dał był ociec mój 1000 zł" ${ }^{57}$ (dokument z 12 czerwca 1660 r.). Nie wiadomo przy tym, kiedy wspomniane transakcje kupna lub zastawu zostały przeprowadzone. Oczywiście należy tu wziąć pod uwagę kwestię zawodności pamięci ludzkiej, w dużej mierze będącej wypadkową odległości czasowej od konkretnego wydarzenia i znaczenia przypisywanego przez określone osoby sprawom materialnym. Jak wskazują na to rozmaite, wcale nierzadkie przykłady, sporządzający akty ultimae voluntatis podawali także wartość mobiliów w przybliżeniu. Podobne sytuacje obserwujemy analizując

\footnotetext{
53 ANKr., CCR, sygn. 769, s. 1527-1531.

54 Źródła i materiały. 2014, s. 144.

55 ANKr., CCR, sygn. 769, s. 1528, 1530-1531.

56 Zob. ostatnio: Letkiewicz E. 2011.

57 Cui contingit. 2005, s. 116.
} 
treści zawarte w pośmiertnych inwentarzach rzeczy $^{58}$. W niektórych testamentach i inwentarzach spisanych post mortem zamieszczane są bowiem wzmianki o dokonanych wcześniej otaksowaniach przedmiotów. Ponadto, czasami niemal za pewnik można przyjąć, że przy spisywaniu testamentu lub rejestru ruchomości korzystano bezpośrednio z dokumentu zawierającego wycenę mobiliów ${ }^{59}$. Wiadomo również, że przy sporządzaniu tzw. opisania sched albo aktu divisionis bonorum mobiliów, powszechnie posługiwano się właśnie zamówionymi uprzednio wycenami ruchomości spadkodawcy ${ }^{60}$.

W tej sytuacji, biorąc pod uwagę wysoki stopień wiarygodności analizowanego rodzaju źródeł, oraz fakt, że wielokrotnie były one podstawą dla tworzenia dokumentów innego typu, obrazujących kulturę materialną szlachty doby nowożytnej, z pewnością warto kontynuować poszukiwania archiwalne w celu zgromadzenia znacznie większego zbioru taks niż wykorzystany w niniejszym artykule oraz przeprowadzenia wszechstronnej i wielowątkowej ich analizy.

\section{ANEKS}

Dokument nr 1: Taksy ruchomości po zmarłych urodzonych małżonkach Chrząstowskich z 2 grudnia 1686 r. Do oblaty wniósł 3 XII 1686 r. honestus Paweł Skalski, ANKr., CCR, sygn. 770, s. 1888-1892.

Źródło zostało wydane stosownie do wskazówek instrukcji wydawniczej dla źródeł nowożytnych, zob.: Lepszy K. 1953.

[s. 1888] Taksa rzeczy pozostałych po JMPP Chrząstowskich roku Pańskiego 1686, dnia 2 miesiąca grudnia.

Taksa futer. Popielice opuszone ogonkami, z wykładami i kołnierz. Naprzód same popielice zł 10. Ogonki [s. 1889] co na wykładach na kołnierzu i na łapciach zł 15. Czapka sobola aksamitna zł 40. Ite $[\mathrm{m}]$ rękaw sobolczykowy farbowany zł 6. Ite $[\mathrm{m}]$ pupki wytarte spod kabata czarnego zł 6. Brzuszki spod płaszczyka przetarte i z kołnierzem zł 6. Suma 80 i 3. Jan Rychlicki, na ten czas starszy.

Taksa sukien, tak białogłowskich jako i męskich. Suknia tabinu francuskiego obłóczysta z kabatem z koronkami zł 100. Suknia atłasowa zielona z koronkami marcypanowemi i kabat zł 100. Spódnica kitajkowa w paski styrana i z kabatem zł 8. Westa kitajkowa pomorańczowa nadchodzona zł 6. Kabat czarny aksamitny z guzikami srebrnemi robotą szmuklerską zł 18. Westa burkatelowa ze złotym kwiatkiem z koronką srebrną zł 24. Suknia czarna tabinku francuskiego z kabatem styranym zł 5. Płaszczyk półlamowy z starego przerabiany z koroneczką małą marcypanową zł 12. Sznurówka atłasowa kaczorowa ze złotym galonkiem zł 8. Zarękawki atłasowe karmazynowe styrane zł 1, gr 15. Kołdra atłasowa papuzia z frandzelką, nadtyrana, [s. 1890] zł 18. Do niej płotek adamaszkowy z koronką maluśką zł 12. Kontusz niebieski tercynellowy z pętliczkami szmuklerską robotą złotymi, nadbrukany, zł 30. Kontusz tabinku francuskiego pomorańczowy z pętliczkami srebrnemi szmuklerską robotą, pobrukany, zł 20. Jupka półlamowa niebieska nadtyrana zł 10. Żupan pomorańczowy atłasowy zł 30. Suma zł 400 i 2, gr 15. Andrzej Koczewicz, cechmagister cechu krawieckiego krakowskiego, Andrzej Kędzierski, starsi cechu krawieckiego krakowskiego.

Taksa srebra ad insta[nti]am $G[e] n[$ er $]$ osi Stephani Czerny facta in anno Domini 1686, die secunda Decembris [2XII]. My niżej podpisani starsi szacowaliśmy i ważyli. Garnuszek gładki próby ośmej, waży grzywnę, łotów półtrzecia, facit - grzywnę rachują po złotych

58 Pielas J. 2021 (w druku).

59 Pielas J. 2021 (w druku).

${ }^{60}$ Pielas J. 2013, s. 324-331. 
24 — zł 26. Łyżek pięć próby jedenastej, w których grzywna i łotów dwa, grzywnę rachują po zł 32 - facit 36. Czareczka mała wewnątrz złocista, waży łotów dwa — zł 4. Srebro od wachlarza — zł 4. Srebro od książek — zł 4. Kanaczek [s. 1891] rubinowy, w którym sztuczek jest numero czterdzieści i jedna — zł 150 i 5. Nożyk z widełkami i nożenki pojedynkowe — zł 6. Srebro na szabli szacowane — zł 52. Pierścień z miąższym diamentem, szmelc koło niego — zł 40. Drugi pierścień diamentowy z białym szmelcem — zł 36. Zaus[z]niczki po jednym diamenciku i po perle niemałej, do uszu są dwoje — zł 26. Wężyki dwa złote szmelcowane - zł 12. Dwie sznurze pereł kałakuckich, które ważą dwa łoty bez ćwierci — zł 160. Trzy sznurki mniejszych pereł — zł 40 i 5. Pacierze koralowe, ważą łotów pięć bez metala — zł 20. Summa facit zł 620 i 6. Jakub Gielteus, starszy złotnik krakowski. Błażej Hadlikowicz, na ten czas starszy.

Taksa chust. Obrusów dwa - zł 9. Poszwa rąbkowa lepsza z forbotkami — zł 15. Poszwa z płótna śląskiego dobra — zł 10. Poszwy trzy — zł 11. Poszewki trzy rąbkowe i z płotkiem — zł 14. Poszewki trzy cienkie rąbkowe z płotkiem — zł 13. [s. 1892] Poszewki trzy sztuczkowego płótna z płotkiem — zł 10. Poszewki trzy rąbkowe i płotek — zł 11. Poszewki trzy sztuczkowego płótna z płotkiem — zł 10. Poszewki trzy prostego płótna z płotkiem — zł 4. Poszeweczki cztery — zł 1, gr 10. Botuch i prześcieradło — zł 3. Poszeweczki trzy rąbkowe — zł 2. Ręcznik jeden, serwet jedynaście — zł 2, gr 18. Gzła dwie a trzecie złe — zł 8. Koszulek sześć złych a siódma dobra, za które facit zł 6. Fartuszków pięć — zł 6. Koszula bawełnicowa turecka — zł 5. Rękawy do gzła naszywane jedwabiem i srebrem — zł 10. Półek sześć na poszewki, złotem szyte — zł 40. Tuwalnia jedwabiem zielonym i złotem przeszywana — zł 18. Płotek jedwabiem zielonym i złotem przeszywany — zł 15. Tuwalnia białym szyciem a gotuwalnia czarnym — zł 8. Zofia Kneblowa. Jadwiga Wiśniowczykowa.

Adres Autora:

dr hab. Jacek Pielas, prof. UJK

Uniwersytet Jana Kochanowskiego w Kielcach

ul. Świętokrzyska 15

25-406 Kielce

jpielas@ujk.edu.pl

https://orcid.org/0000-0002-7165-8905

\section{BIBLIOGRAFIA}

\section{Źródla archiwalne}

ANKr. [Archiwum Narodowe w Krakowie], CCR [Castrensia Cracoviensia Relationes], sygn. 769, 770, 771, 777, 778, 781, 783, 786, 790, 791, 793.

\section{Źródła i opracowania publikowane}

Cui contingit. 2005. Cui contingit nasci, restat mori. Wybór testamentów staropolskich z województwa sandomierskiego, oprac. M. Lubczyński, J. Pielas, H. Suchojad, Warszawa.

Dumanowski Jarosław. 2006. Świat rzeczy szlachty wielkopolskiej w XVIII wieku, Torun.

Głowacka-Penczyńska Anetta. 2013. Rzeczy ,stare” $i$ „,cenne” w testamentach i inwentarzach mieszczańskich małych miast Wielkopolski w XVII w., „Kwartalnik Historii Kultury Materialnej”, R. LXI, nr 2, s. 327-338.

Hoszowski Konstanty. 1862. O znakomitych zastugach w kraju rodziny Korycińskich, Kraków.

Justyniarska-Chojak Katarzyna. 2020. Inwentarze pośmiertne z małych i średnich miast Matopolski (w XVI-XVIII wieku), Kielce. 
Kicińska Urszula. 2017. Splendory domowe w staropolskich inwentarzach ruchomości, „Kwartalnik Historii Kultury Materialnej”, R. LXV, nr 4, s. 461-470.

Klint Paweł. 2011. Testamenty szlacheckie z ksiag grodzkich wielkopolskich z lat 1657-1680, Wrocław.

Klonder Andrzej. 2000. „Wszystka spuścizna w Bogu spoczywajacego”. Majątek ruchomy zwyktych mieszkańców Elblaga i Gdańska w XVII wieku, Warszawa.

Lepszy Kazimierz. 1953. Instrukcja wydawnicza dla źródet historycznych od XVI do połowy XIX w., Wrocław.

Lepszy Leonard. 1898. Cech złotniczy w Krakowie, „Rocznik Krakowski”, t. 1, s. 135-268.

Letkiewicz Ewa. 2011. Klejnoty w osiemnastowiecznej Polsce, Lublin.

Lubczyński Mariusz. 2001. Zawieranie matżeństw przez szlachtę w świetle intercyz przedślubnych oblatowanych $w$ krakowskich ksiegach grodzkich w latach 1680-1730, [w:] Wesela, chrzciny i pogrzeby w XVI-XVIII wieku. Kultura życia i śmierci, red. H. Suchojad, Warszawa, s. $137-156$.

Penkała-Jastrzębska Anna. 2020. Mit srebrnej łyżeczki? Przedmioty prestiżowe w szlacheckich inwentarzach majątkowych z ksiag grodzkich województwa krakowskiego w czasach saskich, „Kwartalnik Historyczny”, R. CXXVII, nr 1, s. 34-40, http://dx.doi.org/10.12775/KH.2020. 127.1.02.

Pielas Jacek. 2013. Podziały majątkowe szlachty koronnej w XVII wieku, Kielce.

Pielas Jacek. 2021. Wartość materialna mobiliów szlacheckich w XVII-XVIII w-uwagi wstęne i perspektywy badawcze (na podstawie źródet dokumentujacych spadkobrania ruchomości $z$ drugiej połowy XVII i początków XVIII w. z terenu Małopolski), w druku.

Pośpiech Andrzej. 1992. Pułapka oczywistości. Pośmiertne spisy ruchomości szlachty wielkopolskiej z XVII wieku, Warszawa.

Pośpiech Andrzej. 1996. Rzeczy stare w pośmiertnych szlacheckich inwentarzach ruchomości z XVII wieku, „Kwartalnik Historii Kultury Materialnej”, R. XLIV, nr 4, s. 377-385.

Źródła i materiały. 2014. Źródła i materiały do dziejów szlachty województwa sandomierskiego w XVI-XVIII wieku, t. 3: Akty podziałów dóbr ziemskich szlachty sandomierskiej z XVII wieku, wstęp i oprac. J. Pielas, Kielce.

\section{Valuations of noblemen's movables from the Kraków nobility court records from the end of the 17 th and the beginning of the 18th century}

This article discusses the analysis of very specific sources — valuations of the nobility's movable property - and attempts to construct a definition of a "valuation of movables" as a separate type of document. Following the analysis of different types of sources concerning the material culture of the nobility, it was established that valuations of movables are assessments of the value of movables of a certain category commissioned by an interested party, made by representatives of town guilds or people practically involved in the valuation of objects, prepared at a certain time and certified with the signatures of those making the valuation, and — in the case of valuers being guild representatives — also with the guild seal.

The study is based on 31 valuations of the nobility's movables identified as a result of a survey of the records of the Kraków nobility court for the years 1685-1710. The documents have been analysed in terms of their structure and content. Attention was paid to a number of issues associated with these documents, such as the categories of valued movables, the circumstances in which valuations were made, including the valuers themselves, as well as the reasons why the nobility decided to commission valuation of various objects.

It was emphasised that the value of the movables listed in the valuation reports allows us to learn the real value, unambiguously expressed in monetary terms, of certain types of the no- 
bility's moveable assets in the analysed period — both the most valuable items as well as old and worn-out objects. In the paper, the Author emphasises the need to continue research on this type of sources.

The appendix contains an edition of one of the more interesting valuation reports discovered during the survey - a valuation of furs, clothing, silver, and scarves left by the deceased married couple Chrząstowski from 1686.

Translated by Karolina Płoska

Proofread by

Rebecca Gorzynska 